\title{
Analysis and Policy Recommendations for New Energy Overcapacity Problem in China-- Wind and Solar Energy Industry as Example
}

\author{
Tingfa Zhang ${ }^{1, a^{*}}$, Peng Sun ${ }^{2, b}$ and Weishuang $\mathrm{Xu}^{3, \mathrm{c}}$ \\ ${ }^{1,2,3}$ School of Economics and Management, Qilu Normal University, China \\ attsdu2011@163.com, balexsp@163.com, xwsjn@163.com
}

Keywords: New energy; Overcapacity; Wind energy; Solar energy.

\begin{abstract}
In recent years, part of the new energy industry in China has appeared a certain degree of excess capacity. This problem causes the bottleneck phenomenon, including the mismatch both wind farm construction and power grid construction, lacking the ability to form a complete set of grid, new energy prices not reacting to its positive externalities, there is also a new energy enterprise technical level which is not high in China, local governments in the achievement of new energy driven by the reason of excessive investment, etc. Aiming at the existence of these temporary short-term problems, this paper also puts forward the corresponding policy recommendations.
\end{abstract}

\section{Introduction}

Since entering the new century, along with the rapid development of China's economy, overcapacity problem has become a big problem in the development of the Chinese economy, correspondingly, the governance of excess capacity is developed into top priority of the China's industrial structure adjustment task. In 2012, the government work report emphasized this problem again, so the problem of China's new energy excess capacity has been existed for quite some time. As the momentum of economic growth, many governments compete to invest the new energy industry that has had a huge development space, similarly China also includes the new energy, energy conservation and environmental protection industries as the focus on cultivating and developing strategic emerging industries. In this context, the overcapacity problems in China's emerging industries have aroused people's concern and thinking.

\section{Development Situation of the New Energy in the World}

Development Situation of the New Energy. Since the end of the 20th century, the impact of the new energy potential is received great attention around the world. On the one hand, new energy sources such as wind power and solar energy has the property of environment friendship, and will not lead to a series of ecological and economic problems; On the other hand, due to the traditional fossil energy reserves have access to the exhausted state, the use and development of new energy is the key factor to to maintain the level of the world economy science and technology in the future. The development and utilization of new energy has been brought gradually into the energy development system by governments, and strengthened in recent years.

Overview of the New Energy and the Current Excess Capacity in China. Wind power, photovoltaic power generation in China started in 2000 for 15 years of rapid development. By the end of 2011, China's new energy generating capacity is about 93.355 billion KWH accounting for about $2 \%$ of the total generating capacity. Among them, the grid wind power generating capacity is 73.174 billion $\mathrm{KWH}$, accounting for $78.38 \%$ of the grid new energy power generation; Grid solar power generating capacity is 914 million $\mathrm{KWH}$, accounting for about $0.98 \%$; Biomass power generation capacity is 19.121 billion $\mathrm{KWH}$, accounting for about 20.48\%; Geothermal and ocean energy generating capacity is 146 million $\mathrm{KWH}$, accounting for about $0.16 \%$. 
Table 1 China's new energy power generation by the end of 2011

\begin{tabular}{|l|l|l|l|l|}
\hline & $\begin{array}{l}\text { wind } \\
\text { power }\end{array}$ & solar power & $\begin{array}{l}\text { biomass } \\
\text { power }\end{array}$ & $\begin{array}{l}\text { geothermal and } \\
\text { ocean energy }\end{array}$ \\
\hline generating capacity( billion KWH) & 73.174 & 0.914 & 19.121 & 0.146 \\
\hline percentage & $78.38 \%$ & $0.98 \%$ & $20.48 \%$ & $0.16 \%$ \\
\hline
\end{tabular}

At present, the proportion of wind power in new energy power generation is very big and speed development on wind power is very fast in China. China's wind power installed capacity newly increased in 201530 megawatts (GW) which occupied $46 \%$ of all the increment in the world, and wind power installed accumulative capacity achieves $62.7 \mathrm{GW}$, which is in the first place in the world. In terms of photovoltaic production, under the pull of foreign products market demand, our country has become the world's largest producer of photovoltaic products. Until 2011, China's photovoltaic products production capacity is $30 \mathrm{GW}$, accounting for $60 \%$ of the world's total capacity. The new installed capacity of global PV market reached $38.7 \mathrm{GW}$ in 2013 , the cumulative installed capacity reached $140.6 \mathrm{GW}$, where Chinese new installed capacity was $12 \mathrm{GW}$ which was close to the sum of newly installed capacity in Europe in 2013. By the end of 2015, China's cumulative solar photovoltaic power generation and network capacity has reached 41.58 million kilowatts, an increase of $67.3 \%$, accounting for $1 / 5$ of the world, but at the same time, the German photovoltaic power generation capacity of $3960 \mathrm{MW}$ by the end of 2015, so China has surpassed Germany as the world's superpower photovoltaic. In addition, in "Twelve Five-year" period, average annual growth of solar power generation capacity has reached $177 \%$.

According to previous analysis, it is obvious that the global PV market has gradually shifted from Europe to Asia as the core area and China has overtaken Germany to become the world's first largest PV market. For example, China has not only eight seats in the world's ten biggest solar photovoltaic battery manufacturers, but also the number of the PV enterprises in our country from less than 100 in 2008 has been expanding to nearly 600 .

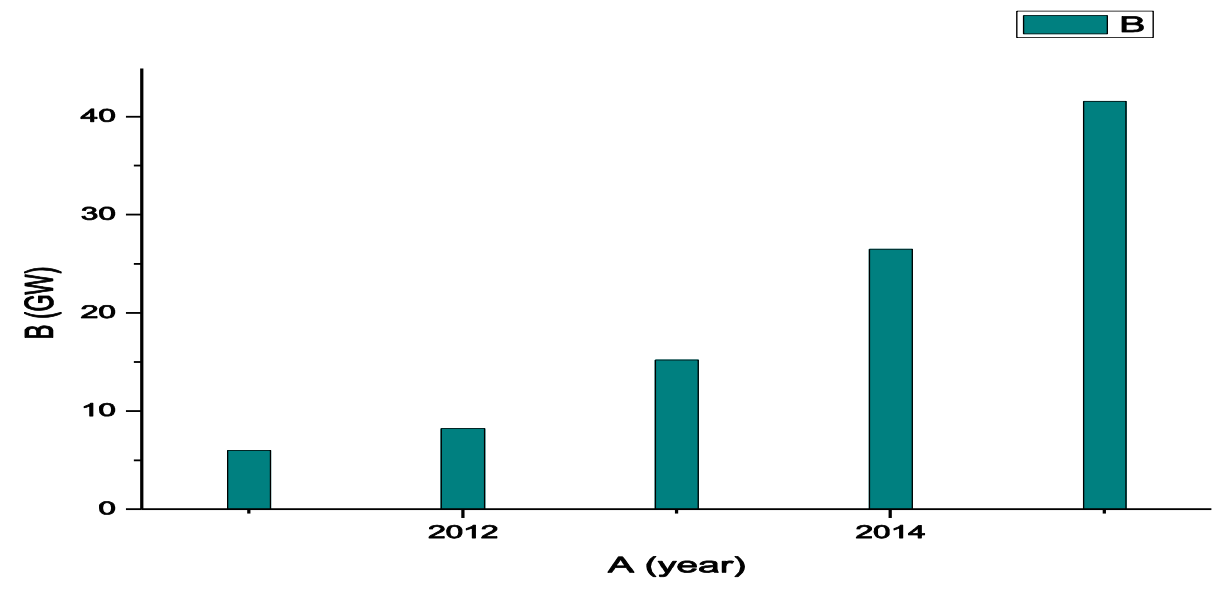

Figure 1. Chinese photovoltaic power capacity in 2011-2015

Table 2 China's photovoltaic cell production and growth in comparison with the world

\begin{tabular}{|l|l|l|l|l|l|l|}
\hline & 2005 & 2006 & 2007 & 2008 & 2009 & 2010 \\
\hline $\begin{array}{l}\text { Chinese } \\
\text { production(NW) }\end{array}$ & 146 & 438 & 1088 & 260 & 4100 & 13500 \\
\hline $\begin{array}{l}\text { World } \\
\text { production(NW) }\end{array}$ & 1819 & 2536 & 1279 & 7911 & 12626 & 27213 \\
\hline China accounted for & $8.02 \%$ & $17.27 \%$ & $25.43 \%$ & $32.87 \%$ & $32.47 \%$ & $49.61 \%$ \\
\hline
\end{tabular}

China's New Energy Surplus Performance at Present. First, time mismatch of Wind farm construction and power grid facilities construction. There is a considerable gap between China's wind 
power installed capacity and the actual grid capacity and, the cause of this situation is that the progress of construction of the wind farm and power grid construction is not harmonious. At present, approval and construction cycle of China's wind power facilities mismatch, so that a portion of wind power capacity can not be achieved in a timely manner and the network, resulting in a temporary overcapacity.

Second, Insufficient supporting capacity of the grid system. On the one hand, wind power and other power planning is inconsistent. Since wind energy has a random, changeable, intermittent characteristics, and therefore need additional flexibility in the operation of a certain size to match the energy to increase peaking capacity of the grid to ensure the smooth operation of the power grid. Moreover, China's wind power is still in its infancy, wind power and other energy planning and energy planning is not coordinated, and even conflict, so that the operation of wind power often there will be "abandoning the wind" phenomenon. On the other hand, the demand for electricity and wind power supply side do not match, relatively weak power grid planning.

Finally, New energy prices on the high side, compressing the effective demand of the market. Compared with traditional energy generation, new energy power generation cost is relatively high, resulting in new energy generation companies in the bidding certainly at a competitive disadvantage. From the specific data, the current average cost of thermal power generation is $0.24 \sim 0.35$ yuan /degree, although in recent years the wind power production efficiency has been greatly improved, but still in the 0.51 to 0.61 yuan / degree higher price, furthermore, the cost of photovoltaic power generation is at around 0.73 to 0.99 yuan / degree, the significant difference in the cost will make rational grid companies choose low-cost sources of power generation where possible.

\section{Analysis of the Causes of New Energy Development Overcapacity}

Not High Technical Level of New Energy Enterprises in China. At present, most of the domestic photovoltaic companies do not have the advanced core technology and have a cost disadvantage compared with foreign enterprises under the same circumstances. For example, average conversion efficiency of Chinese enterprises for the production of polysilicon by the trichlorosilane is about $10 \%$, $14 \%$ overseas; power consumption of most of the polysilicon producers is $180 \sim 200 \mathrm{KWH} / \mathrm{kg}$ in China, while foreign companies about $120 \mathrm{kwh} / \mathrm{kg}$. In contrast, China's photovoltaic power production enterprises are high electric consumption and high cost. In the absence of core technology support, these companies profitable way only rely on cheap Chinese labors to engage in low-end photovoltaic products, which can not only waste the limited economic resources and influence the average profit of the market, but also is not conducive for photovoltaic technology optimization and upgrading.

Over-Reliance on Foreign Markets is a Direct Factor of Excess Capacity. China's photovoltaic solar energy market structure showing the situation of raw materials and final products "two out" before 2007 is unreasonable, and the current sales of photovoltaic products is still a demand-led European countries, because of too much dependence on external markets, domestic demand for PV products only accounts for only $5 \%$ to $10 \%$, the remaining $90 \%$ of the photovoltaic products are for export. The EU is the most important demand side of photovoltaic products, accounting for about $80 \%$ share of the market demand. But from 2010 , due to the economic downturn in Europe and the average cost decline of photovoltaic power generation, the EU subsidies for photovoltaic power generation has reduced by $10 \%$ to $30 \%$. Accordingly, the EU demand for photovoltaic products have also decreased greatly, furthermore, European PV market demand drop will be a huge impact on China who has a strong impact in the short term and the situation of production of excess capacity is difficult to avoid as the world's largest solar cell supply side.

Driving Factors of the Local Government to Develop New Energy Achievements. By the end of 2010, the number of new energy base has been more than 100 all over the country, whose sizes are relatively large. Driven by "the pursuit of excellence" achievements, local government want each new energy base to achieve the domestic and the world first-class level as the goal, such as "three gorges in 
wind power" and "China sun city" and so on, so local governments enthusiasm for the development of new energy is much higher than the desired degree of central policies.. By the end of 2010, in the national grid and construction of wind power projects, local projects accounted for $77 \%$, while the state approved only $23 \%$.

In addition, because the potential target for the local government function is not based on the national macroeconomic situation, they just want the rapid development of new energy industry in their respective regions, and will not pay attention to the country-level development of new energy industries; at the same time, driven by performance goals, some local governments may also adopt local protectionism to protect local production of some low-end production capacity items regardless of the cost benefits, which will thereby exacerbate the industry overcapacity in the short term.

\section{Corresponding Policy}

Construction and Development of New Energy not be Terminated or Excessively Slow Down. Although China currently appears a certain degree of excess capacity, such as wind power, solar photovoltaic and other new energy industries, but we can not slow down the pace of development of new energy just because of such short-term structural imbalances.

The current stock of traditional fossil energy sources has slightly shortage, energy efficiency and improving energy productivity level is relatively limited, and energy efficiency and the development of new energy has great potential for development space, so seize the opportunity of the new energy revolution China's economic restructuring and the implementation of the catch-up strategy has a very important significance;

Second, the development of new energy will help alleviate the pressure on the environment we are facing. Fossil fuels provide support for the economic development of our country at the same time, a lot of greenhouse gas, sulfur dioxide and other polluting gases will generate not only more strong negative externalities, but also increase the reduction pressure from western countries in the climate negotiations.

Reform of the New Energy Pricing Mechanism. As the existing thermal power price does not include the negative externalities they have caused, so its nominal price has very big deviation than the actual price, if such price differences persist, the development of new energy power generation would be greatly suppressed. For this situation, China's relevant departments can gradually try to introduce a carbon emissions tax, pollution tax rate increase so that thermal power generation and other traditional way prices can truly reflect their costs. Thus, the price of new energy power generation will contain their environmental value in order to make China's new energy industry to obtain real development in the market competition.

Raise the Level of the Core Technology of New Energy Enterprises. The new energy industry in China still is given priority to low capacity, energy conversion efficiency is not high, specially wind turbine bearings, light power generation, the technology, key equipment and technology also need a large number to be imported from abroad. The government can't just rely on subsidies of production cost in new energy industry to maintain its existence, but need have a foothold in the long run, more subsidies for construction of research and development laboratory to achieve a fundamental technological breakthrough.

Optimize the Market Structure of the New Energy. We have to change the new energy market driven by the government as the dominant mode and let the market naturally optimize the structure according to economic laws, the government needs to support the market so that the price mechanism can works such as to formulate various laws and regulations in the field of new energy and encourage the preferential policy, restrict some low-end without core technology enterprises blindly into the market, etc.

Also, the government has to encourage mergers and acquisitions of new energy industry, adhere to the survival of the fittest, allow the emergence of leading enterprises, improve the industrial concentration, and realize scale effect. At the same time, the large core enterprises are more 
conducive to technology research and development progress, promoting the rapid development of industry.

\section{References}

[1] K Parikh. Sustainable development and low carbon growth strategy for India, J. Energy, Vol.40 (1994) No.1, 31-38.

[2] Furman, J.L., Porter, M.E., Stern, S. The determinants of national innovative capacity, J. Research Policy, 2002, 31(6):899-933. Vol.31 (2002) No.6, 899-933.

[3] UK Rout. Prospects of India's energy and emissions for a long time frame, J. Energy Policy, 2011,39(9):5647-5663 Vol.39 (2011) No.9, 5647-5663.

[4] P Balachandra, D Ravindranath, NH Ravindranath. Energy efficiency in India: Assessing the policy regimes and their impacts [J]. Energy Policy, 2010, 38(11):6248-6438.

[5] Hu, X., Murgovski, N., Johannesson, L., Egardt, B. Energy efficiency analysis of a series plug-in hybrid electric bus with different energy management strate gies and battery sizes,J. Energy, Vol.111 (2013) No.11, 1001-1009.

[6] Ding, Y., Yang, H. Promoting energy-saving and environmentally friendlygeneration dispatching model in China: phase development and case studies, J. Energy Policy, Vol.57 (2013) No.6, $109-118$.

[7] Gao, C., Li, Y., Evolution of China's power dispatch principle and the newenergy saving power dispatch policy, J. Energy Policy, Vol.38 (2010) No.11, 17346-7357.

[8] Ji, S., Cherry, C.R.,J., Bechle, M., Wu, Y., Marshall, J.D. Electric vehicles in China:emissions and health impacts, J. Environ. Sci. Technol, 2012, 46 (4), 2018-2024.

[9] Stern N. The Economics of Climate Change [M]. London: Cambridge University Press, 2006.

[10] IPCC. Climate Change 2007: migitation. Contribution of Working GroupIII. To the Fourth Assessment Report of the Intergovernmental Panel on Climate Change[R]. London: Cambridge University Press., 2007. 